\title{
POLAR BEARS
}

\section{At Cape Churchill, Manitoba}

\author{
by GEORGE HOCHBAUM*
}

While banding Canada Geese for the Manitoba Government on Cape Churchill, I had the opportunity to make daily observations of polar bears from July 16 through July 28, 1968. Our base camp was about 45 miles east of the townsite of Churchill, half a mile inland from the west shore of Hudson Bay and some 25 miles north of tree line. The area is characterized by many gravel beachlines parallel to the coast and separated by lowlands holding many small, shallow lakes bordered with willows.

Polar bears were seen every day, isually in the early morning or late afternoon and early evening. Bears vere seldom observed to venture far rom shore and most sightings were made from a small point which jutted ut into the Bay. Clearly, bears related heir feeding activities to the tide, noving away from shore before 10 a.m. to search the tide flats for food. They returned to the shoreline with the ncoming flow between 4 and 7 p.m.

On the point from which I made nost of my observations, and clsewhere along the coastline, I found shallow beds or pits which had been dug by bears. These averaged about 4 feet in diameter, dug in at a slight angle to level ground. Several times in late afternoon I saw bears in these pits, either sitting or lying with their hindquarters within the pit, invariably the bears faced down-wind. On one occasion I chanced upon a bear in a pit, casually eating willow roots. Twice I saw bears leave scent at their beds,

* Institute of Animal Resource Ecology,

University of British Columbia,

Vancouver 8, British Columbia. urinating on nearby pieces of driftwood. Each of these bears was observed to lift its leg, much in the manner of a domestic dog.

I never saw more than one bear in the vicinity of our camp at any one time, but I suspect from differences in their size and appearance that from three to five were using the area, renowned as a summer gathering place for polar bears. I also suspect that these were adult males or immatures which had not reached breeding age.

This local gathering of bears may have been influenced by the presence of a dead beluga whale which had drifted ashore near the point. On several evenings I saw single bears come to feed on the whale. The longest feeding period was 30 minutes by a bear which during this period rolled on the decomposing whale several times.

The polar bears on Cape Churchill were not as easily approached as are the bears at the Churchill garbage dump during their fall concentration there. When bears noticed my presence, they quickly retreated to the Bay.

Editor's Note: Anyone interested in more information on polar bears is urged to write for a copy of the beautifully illustrated, 16 page brochure entitled The Great White Bears by R. W. Nero. It is available free from the Department of Mines, Resources and Environmental Management, Winnipeg. Manitoba. 